\title{
How (Difficult Is It) to Build Consensus on (European) Consensus?
}

\author{
PANOS KAPOTAS AND VASSILIS P. TZEVELEKOS
}

\subsection{Introduction: The Consensus 'Game'}

'Consensus' is a 'riddle, wrapped in a mystery, inside an enigma.' ${ }^{1}$ It has various meanings, ${ }^{2}$ is used in miscellaneous contexts and for a variety of purposes, and may therefore perform diverse roles. The core component that remains constant across its different definitions, conceptions and uses is the existence of some sort of agreement that enables the 'making' of a decision. Yet, the precise nature and extent of the agreement that underpins consensus is elusive. It spans from anything between a broad, shared understanding (in the sense of concurrence, like-mindedness or general opinion) to (explicit or implied) unanimity that entails a veto power for anyone who participates in the consensus-making process. Different shades of consensus exist between the two extremes of this continuum, depending on the 'looseness' or 'rigidity' of the rules of its formation.

The pluralism or ambiguity - depending on one's point of view - in the conceptualisation of consensus is but one of the complexities with which it is fraught. Even if one were to ignore or avoid the definitional pitfalls, consensus cannot become fully operational as a decision-making tool unless the 'rules of the game' have been established: who are the eligible 'players', what are the conditions of validity for its formulation, what is the effect of a consensus/no-consensus outcome, and who is the arbiter of the outcome, that is, who has the authority to recognise the

1 This famous turn of phrase is borrowed from Winston Churchill, who used it in a BBC radio broadcast on 1st October 1939 to describe Russia's unpredictable reactions. See www.churchill-society-london.org.uk/RusnEnig.html.

${ }^{2}$ See the chapters contained in Part I of this book, and especially Chapters 4 and 8 by C. Djeffal and S. Douglas-Scott, respectively. 
existence of consensus? Clarity in outlining these 'contours' of consensus translates into (legal) certainty on its modus operandi and its outputs. The 'contours', of course, are arguably as important as its definition, as together they are necessary conditions for the functionality of consensus and for its effectiveness. Consensus as a decision-making tool, therefore, encapsulates a paradox: its ability to operate effectively is predicated on the existence of consensus ${ }^{3}$ on its meaning and on the layout of its 'contours'. And this inevitably requires an authority ${ }^{4}$ that will set the rules of the 'game'.

Speaking of games, the allure of consensus apparently transcends the boundaries of academic discourse, judging from the homonymous board game that relies on the assumption that in any given group of people, even the most trivial question is bound to attract a variety of different responses. ${ }^{5}$ The rules of the board game are simple. Each player must vote which of the nouns on their common list best matches the adjective on the board. The answer favoured by the majority of players wins. Thus, in the 'Consensus' game, the majority rules ${ }^{6}$ and the designer of the game is the authority that defines the meaning, function and purpose of the term 'consensus', as well as the framework in which consensus operates (e.g., the conditions of validity for 'contributing' to a consensus outcome, the rules regarding the recognition of a consensus outcome, and the conditions of eligibility for potential players).

This book explores consensus in the context of the system of the European Convention on Human Rights (ECHR). Within this system, the 'players' of the European consensus (EuC) 'game' are prima facie ${ }^{7}$ the signatories to that instrument. The designer of the consensus 'game' and, hence, its rule-setter, is the European Court of Human Rights (ECtHR). This raises two interconnected sets of questions: the first concerns the

3 The intentional pun, which has also inspired the title of this book and its introduction, is gratefully borrowed from L. Wildhaber, A. Hjartarson and S. Donnelly, 'No consensus on consensus? The practice of the European Court of Human Rights' (2013) 33 Human Rights Law Journal 248-63.

${ }^{4}$ See footnote 61. See also V. P. Tzevelekos and K. Dzehtsiarou, 'International custom making and the ECtHR's European consensus method of interpretation' (2016) 16 European Yearbook of Human Rights 313-44.

${ }^{5}$ See http://consensusgame.com/index.php.

${ }^{6}$ As the box cover of the board game eloquently points out.

7 See Section 1.3.1 regarding the constitutive role that the ECtHR may have in the construction of EuC. 
'game' itself and its rules; the second relates to the value of the 'game' in the context of (international) human rights adjudication. These two sets of questions broadly correspond to the first and second Parts of this book, respectively, although the borders between the two are inevitably porous, as attested by several of the chapters contained therein. ${ }^{8}$ The third Part of the book explores the transferability of EuC in other juridical contexts or its comparability with potentially analogous methods employed in different legal systems within and outside Europe, both at the national and the inter/supra-national level.

The remainder of this introductory note is structured as follows. Section 1.2 offers a brief overview of EuC, with the express caveat that its aim is not to convey certainties as to the 'what' and the 'how' of EuC. Had such certainty existed, this book and the scholarly work it hosts would perhaps be redundant. We intentionally limit the overview to what we consider the necessary minimum that readers with no prior knowledge of $\mathrm{EuC}$ will require to approach the rest of the chapters with some confidence. As such, our outline leaves several questions unanswered and should be read with a critical eye. As all aspects of EuC are open to competing and often conflicting interpretations, any attempt to draw a conceptual map can (and should) be open to challenge - and challenging existing knowledge and presumed certainties on $\mathrm{EuC}$ is one of the main objectives of this book. To that end, our outline is primarily designed to raise some of (the very many) questions pertaining to the function, evaluation and transferability of EuC, and to pave the way for the critical analysis that will follow. Section 1.3 endeavours to explain why any attempt to build consensus on EuC is bound to face significant hurdles and to identify the causes of the diverging academic opinions on EuC. It also offers a justification of our (partial) 'agnosticism' vis-à-vis EuC and of our reluctance to provide a more detailed overview of its role and function in this introduction. Section 1.4 describes the contribution this book aspires to make and lays down signposts to guide readers through the structure and the main questions discussed in each of the three Parts. Section 1.5 concludes by acknowledging the limits and limitations of the book, while issuing a rallying call for more research on (European) consensus in human rights adjudication.

${ }^{8}$ See, for example, the chapters in the book by K. Dzehtsiarou (Chapter 2), L. Van den Eynde (Chapter 5), K. Henrard (Chapter 7), A. Follesdal (Chapter 9), T. Kleinlein (Chapter 10) and F. de Londras (Chapter 14). 


\subsection{EuC at a Glance}

The text of the ECHR is general and abstract by design. It is destined to acquire its concrete normative content and produce tangible effects when its laconic provisions are brought to bear on the facts of a specific case through judicial interpretation. In performing this task, the ECtHR can avail itself of a plethora of interpretive methods, techniques and tools. Some of these methods are available to all (international) courts and can be found in the 1969 Vienna Convention on the Law of Treaties (VCLT). ${ }^{9}$ They include resorting to the travaux of the ECHR as a means to identify the original will of the signatories ${ }^{10}$ or investigating the ordinary meaning of a term appearing in the text of the ECHR. ${ }^{11}$ Other interpretive tools may be common across different systems, but acquire a particular gravitas in the ECHR system because of the latter's 'speciality $^{12}$ as a 'constitutional' instrument enshrining foundational European values. ${ }^{13}$ This is, for instance, the case with the use of the 'object and purpose' of human rights law as an interpretive signpost associated with

${ }^{9}$ VCLT, Articles 31-33. On the interrelationship and possible overlap between the methods contained in the VCLT and EuC, see, in this book, the chapters by J. Větrovský (Chapter 6), A. Follesdal (Chapter 9) and especially C. Djeffal (Chapter 4).

10 VCLT, Article 32. See, for example, Banković and Others v. Belgium and Others (Appl. no. 52207/99), decision on admissibility, 12 December 2001, paras 19-21, 58, 63 and 65; Nolan and K. v. Russia (Appl. no. 2512/04), Judgment, 12 February 2009, paras 48 and 110 .

11 VCLT, Article 31(1). See, for example, Banković and Others v. Belgium and Others, para. 65. In this book, see the chapters by L. Lixinski (Chapter 15), C. Djeffal (Chapter 4) and especially J. Větrovský (Chapter 6).

12 The term 'special' is used here not in the sense of lex specialis, but to denote the distinctive importance of (international) human rights law. This distinctiveness is reflected in the classification of international human rights rules as obligations erga omnes and in the legal effects that this class of obligations produces (in particular, collective enforcement). See ILC, A/CN.4/L.682, Fragmentation of International Law: Difficulties Arising from the Diversification and Expansion of International Law, Report of the Study Group of the International Law Commission, Finalized by Martti Koskenniemi, Fifty eighth session, 1 May-9 June and 3 July-11 August 2006, paras 380-409 and, for human rights as a special regime of international law (i.e., a question that partially overlaps with speciality as lex specialis), paras 128-33 and 161-4.

13 ECHR's speciality is linked with the idea of a regional, European public order and transforms the ECHR into a regional 'constitutional' instrument. See, for example, Chrysostomos, Papachrysostomou and Loizidou v. Turkey (Appl. nos. 15299/89, 15300/ 89 and 15318/89), decision on admissibility, 4 March 1991, paras 20 and 22; Loizidou v. Turkey (Appl. no. 15318/89), judgment (on preliminary objections), 23 March 1995, para. 75 . 
the teleological method of interpretation. ${ }^{14}$ Finally, one can also identify tools of interpretation that are exclusive to the ECtHR. ${ }^{15}$ Whether or not $\mathrm{EuC}$ is, indeed, one such tool, is very much an open question. Strong arguments could be made that similar methods of interpretation are well established in other legal systems, ${ }^{16}$ or that EuC overlaps with and may even be seen as a particular type of the evolutive/dynamic method of interpretation, which clearly extends beyond the confines of the ECHR system. ${ }^{17}$ But this is not a question that we wish to consider here. Instead, what we argue is that EuC is, perhaps, not exclusive to the ECHR system, but is certainly an idiosyncratically European method of interpretation. This is not only because EuC, as a method (or a set of methods ${ }^{18}$ ) of interpretation, has been 'invented' and developed by the ECtHR, but also because its raison d'être is to act as a barometer of evolution primarily, if not exclusively, within the European continent. This raises complex questions regarding the precise role EuC must play in the ECHR interpretive ecosystem, especially in view of its seemingly symbiotic

${ }^{14}$ VCLT, Article 31(1). In the ECHR system, the object and purpose of the Convention are associated with the principle of effectiveness, that is, the Convention's effet utile, and the idea that the rights it enshrines ought to be 'practical and effective, not theoretical and illusory'. See the origins of the principle of effectiveness in Marckx v. Belgium (Appl. no. 6833/74), judgment, 13 June 1979, para. 31; Airey v. Ireland (Appl. no. 6289/73), judgment, 9 October 1979, para. 24.

15 For instance, the margin of appreciation doctrine (footnote 68) or the autonomous interpretation (originating from Engels and others v. the Netherlands, Appl. nos. 5100/ $71 ; 5101 / 71 ; 5102 / 71 ; 5354 / 72 ; 5370 / 72$, judgment, 8 June 1976, para. 81 ) are, arguably, unique to the ECHR system, in the sense that they have been created by the ECtHR (irrespective of possible subsequent 'spill-over' to other legal systems).

16 See all the chapters in Part III of this book.

${ }^{17}$ In the ECHR system, evolutive interpretation is associated with the living instrument doctrine, which requires the Convention to be interpreted in light of present-day conditions. It originates from Tyrer v. the United Kingdom (Appl. no. 5856/72), judgment, 25 April 1978, para. 31. On evolutive interpretation, see footnote 66. See also VCLT, Article 31(3)(c), V. P. Tzevelekos, 'The use of Article 31(3)(c) of the VCLT in the case-law of the ECtHR. An effective anti-fragmentation tool or a selective loophole for the reinforcement of the teleology of human rights? Between evolution and systemic integration' (2010) 31 Michigan Journal of International Law 621-90 and ILC, A/CN.4/L.682, paras $410-80$.

18 According to Dzehtsiarou, for instance, consensus can be classified into four types: consensus stemming from the comparative analysis of the laws and practice of the signatories to the ECHR, consensus based on international treaties, internal consensus within the respondent state(s), and (scientific) consensus among experts. K. Dzehtsiarou, European Consensus and the Legitimacy of the European Court of Human Rights (Cambridge: Cambridge University Press, 2015), pp. 39-56. See also Wildhaber, Hjartarson and Donnelly, 'No consensus on consensus?', 252-6. 
relationship with the evolutive method of interpretation, ${ }^{19}$ but also in situations in which European and international trends are not moving in the same direction. ${ }^{20}$

A common hypothesis is that the ECtHR is particularly keen on employing the EuC method when it is faced with (morally, politically or socially) sensitive, controversial or ambiguous questions. It is well known that the Court enjoys discretion in choosing the most appropriate method(s) of interpretation for each case. But it is exactly this discretion that makes it difficult to pinpoint what triggers the use of EuC in some cases but not in others and makes it even more difficult to gauge whether $\mathrm{EuC}$ is being used consistently across different types of issues involving different Convention rights. This is all the more troubling when one considers that the function of EuC is such that the ECtHR will often resort to it in order to identify the emergence (or not) of a common standard with regard to a particular question of interpretation. It is evident, then, that the issues of selectivity and (in)consistency in the use of $\mathrm{EuC}$ are but the tip of a pretty sizeable iceberg. In fact, the list of questions is virtually endless, ranging from the more abstract philosophical difficulties in fixing the position of $\mathrm{EuC}$ within the normative foundations of the ECHR and in establishing the authority of the Court to rely on it, to the more 'technical' problems of deciphering the 'ingredients' that make up $\mathrm{EuC}^{21}$ detecting the types of human rights questions that are suitable for consensus analysis and ascertaining whether 'consensus exclusion zones' may exist within the Convention. ${ }^{22}$ Per our earlier disclaimer, we will tread with caution and refrain from taking a

19 For instance, all the chapters in this book refer to the interrelationship between the margin of appreciation and EuC. See in particular the chapters by S. Douglas-Scott (Chapter 8), A. Follesdal (Chapter 9), K. Henrard (Chapter 7) and especially T. Kleinlein (Chapter 10). See also footnote 68. Regarding evolutive interpretation and its interrelationship with EuC, see, in this volume, for example, the chapters by C. Djeffal (Chapter 4), K. Henrard (Chapter 7), A. Follesdal (Chapter 9) and T. Kleinlein (Chapter 10). See also footnote 66.

${ }^{20}$ See, for example, Christine Goodwin v. the United Kingdom (Appl. no. 28957/95), judgment, 11 July 2002, paras $84-5$, where the absence of EuC was 'remedied' by the existence of an international trend that trumped European states' practice.

${ }^{21}$ See footnote 18 .

22 This is often associated in the literature with counter-majoritarian approaches to human rights, especially regarding the protection of minority rights. In this book, see especially the chapter by D. Kagiaros (Chapter 13). More generally, inter alia, see the seminal works by E. Benvenisti, 'Margin of appreciation, consensus, and universal standards' (1999) 31 New York University Journal of International Law and Politics 843-54 at 848-53; G. Letsas, A Theory of Interpretation of the European Convention on Human Rights 
stance on any of these questions here. Suffice it to say that, among a plethora of possible components, ${ }^{23} \mathrm{EuC}$ consists in the comparative analysis of the prevailing legal trends and common understandings of a right, with a principal focus on the national legal orders of the signatory parties. ${ }^{24}$ The core element of EuC, therefore, is, arguably, practice at the national level, which, in turn, raises yet another set of questions regarding the nature of such practice, the threshold numbers of states needed for a consensus finding, and the thoroughness, transparency and methodological robustness of the comparative exercise undertaken by the ECtHR for the purposes of EuC.

In so far as the effects of $\mathrm{EuC}$ are concerned, things are somewhat clearer. Although one might still argue that the picture is not entirely free from inconsistencies, ${ }^{25}$ it is possible to suggest that, in principle, if the Court diagnoses consensus, it permits itself to establish pan-European standards that are binding on all states under its jurisdiction. ${ }^{26}$ In this regard, EuC may be seen as a tool to expand the semantic scope of the ECHR, possibly beyond the rights that are explicitly included in its text. ${ }^{27}$ In the absence of EuC, states and their national authorities enjoy a wider

(Oxford: Oxford University Press, 2007), especially chapters 3, 5 and 6; Dzehtsiarou, European Consensus, especially pp. 116-29. See also footnote 51.

${ }^{23}$ See footnote 18.

24 See, for example, Konstantin Markin v. Russia (Appl. no. 30078/06), judgment, 22 March 2012, paras $71-5$ and 140 .

25 The obvious example is $A, B$ \& $C$, where the Court went against EuC. See $A, B$ \& $C$ v. Ireland (Appl. no. 25579/05), judgment, 16 December 2010, especially paras 231-37. See, in this book, the chapter by F. de Londras (Chapter 14) and her illuminating discussion of $A, B$ \& $C$.

${ }^{26}$ See, for instance, Council of Europe, Parliamentary Assembly (2000) Execution of Judgments of the European Court of Human Rights. Resolution 1226, para. 3, http:// assembly.coe.int/nw/xml/XRef/Xref-DocDetails-EN.asp?FileID=16834\&lang=EN. 'The principle of solidarity implies that the case-law of the Court forms part of the Convention, thus extending the legally binding force of the Convention erga omnes (to all the other parties). This means that the states parties not only have to execute the judgments of the Court pronounced in cases to which they are party, but also have to take into consideration the possible implications which judgments pronounced in other cases may have for their own legal system and legal practice'.

27 In Vallianatos, for instance, the ECtHR relied on EuC to conclude that the respondent state had violated Article 14 in conjunction with Article 8 of the ECHR because it excluded same-sex couples from the scope of legislation recognising a 'civil union' as an official form of partnership other than marriage. The right to a civil union as an alternative to marriage is not explicitly prescribed in Article 8 ECHR. See Vallianatos and Others (Appl. nos. 29381/09 and 32684/09), judgment, 7 November 2017, especially para. 91. 
margin of appreciation ${ }^{28}$ and the ECtHR typically applies a looser proportionality test in determining the lawfulness of national rules and of executive, administrative or judicial practice that may limit Convention rights. ${ }^{29}$ Therefore, it is possible to argue that the Court exercises judicial self-restraint and, in doing so, it favours the regulatory autonomy of national authorities by empowering them to decide on the matter at issue domestically. This may be described as an expression of the principle of subsidiarity. ${ }^{30}$ As a result, in the absence of EuC, Europe may accommodate multiple human rights standards in the spirit of (constitutional) pluralism. ${ }^{31}$

We conclude this overview by reiterating that the controversy surrounding EuC and the lack of clarity on its meaning, normative place and modus operandi cannot be overplayed. ${ }^{32}$ Our brief tour d'horizon was designed to cover the core of $\mathrm{EuC}$, with a view to providing readers with

28 See, for example, Chapman v. the United Kingdom (Appl. no. 27238/95), judgment, 18 January 2001, paras 93 and 104.

29 Evans v. the United Kingdom (Appl. no. 6339/05), judgment, 10 April 2007, para. 77; Dickson v. the United Kingdom (Appl. no. 44362/04), judgment, 4 December 2007, para. 78.

30 See Article 1 of the 15th Protocol to the ECHR (not yet entered into force) and the connection it establishes between the margin of appreciation and subsidiarity. See also the Brighton declaration, paras 11 and 12, and especially 12(b). European Court of Human Rights, 'High level conference on the future of the European Court of Human Rights' (19-20 April 2012), www.echr.coe.int/Documents/2012_Brighton_FinalDeclaration_ ENG.pdf. See also A. Mowbray, 'Subsidiarity and the European Convention on Human Rights' (2015) 15 Human Rights Law Review 313-41.

31 On constitutional pluralism, see N. Krisch, 'The open architecture of European human rights law' (2008) 71 The Modern Law Review 183. N. Krisch, Beyond Constitutionalism: The Pluralist Structure of Postnational Law (Oxford: Oxford University Press, 2010). For an overview, comparing constitutional pluralism with the constitutionalisation narrative, see L. Lixinski, 'Taming the Fragmentation Monster through Human Rights? International Constitutionalism, "Pluralism Lite" and the Common Territory of the Two European Legal Orders', in V. Kosta et al. (eds.), The EU Accession to the ECHR (Oxford: Hart, 2014), pp. 219-33. For a collection of essays on constitutional pluralism regarding the EU and beyond that legal order, see M. Avbelj and J. Komárek (eds.), Constitutional Pluralism in the European Union and Beyond (Oxford: Hart, 2012). In this book, see especially the chapters by S. Douglas-Scott (Chapter 8) and L. Van den Eynde (Chapter 5).

32 As a former President of the Court has authoritatively explained, no full consensus exists on consensus partly because the 'Court's case-law is in some respects fluid and even fuzzy' (Wildhaber, Hjartarson and Donnelly, 'No consensus on consensus?', 262). It is inevitable, then, that different authors in this book 'read' consensus in different ways. Compare, for instance, the chapters by J. Větrovský (Chapter 6) and O. Bassok (Chapter 11), or the chapters by the latter author (in so far as the concept of public confidence is concerned) and T. Kleinlein (Chapters 11 and 10, respectively). 
little or no background knowledge a basic understanding of the object of this book. We also tried to offer a glimpse of the nature and volume of questions raised by the conceptualisation and modus operandi of EuC. The next section of this introductory chapter identifies the inherent challenges when attempting to study EuC. Its tripartite structure mirrors the division of the book into three Parts.

\subsection{Building Consensus on EuC: Mission Impossible?}

\subsubsection{Impediments to the Conceptualisation of $\mathrm{EuC}$}

As already explained, it is the ECtHR that invented the term 'European consensus' and developed it as an interpretive technique. This entails that the Court enjoys considerable discretion in choosing when to use $\mathrm{EuC}$ together with or instead of other methods of interpretation, in defining what consensus consists in and in evaluating the evidence on convergence of standards in Europe and beyond. ${ }^{33}$ Along the same lines, it is the Court that defines the parameters of the legal question on which consensus is sought, and it is the Court that decides which elements should be taken into account for the purposes of that inquiry. ${ }^{34}$

Yet the designer and game master of the EuC 'game' has not (yet) provided a full, clear and detailed 'manual' on the definition of consensus and on the rules and outputs of the game. ${ }^{35}$ Although the ECHR monitoring system has used the EuC technique from the 1970s onwards, ${ }^{36}$ no comprehensive and authoritative guidance has been forthcoming. For instance, although it is evident that a considerable number of states must have developed a common practice for EuC to emerge, it is unclear where the cut-off point is (i.e., how many states will be required to reach the

33 Tzevelekos and Dzehtsiarou, 'International custom making', 325.

34 As to the discretion the ECtHR enjoys regarding the legal question it will examine, see the dissenting opinion of Judge Tulkens in Leyla Şahin v. Turkey (Appl. no. 44774/98), judgment, 10 November 2005, para. 3 of the opinion. See also Dzehtsiarou, European Consensus, pp. 109-10.

35 We only have limited knowledge based on sporadic guidance provided by the Court and on the work of scholars, who establish hypotheses that lead to varied interpretations as to what $\mathrm{EuC}$ is and how it operates.

36 Tyrer v. the United Kingdom, para. 31; Marckx v. Belgium (Appl. no. 6833/74), judgment, 13 June 1979, para. 41; Dudgeon v. the United Kingdom (Appl. no. 7525/76), judgment, 22 October 1981, para 60. On the origins of EuC in the practice of the ECHR institutions, and especially of the European Commission on Human Rights, see the chapter by E. Bates (Chapter 3) in this volume. 
'consensus' threshold). ${ }^{37}$ In the same vein, no detailed explanation has been provided regarding the different 'shades' of consensus and how these may correspond to the different terms that make up the 'consensus lexicon' employed by the ECtHR. ${ }^{38}$ This might be due to a lack of consensus $^{39}$ (in the sense of an absence of unanimous agreement) among the ECtHR judges, which would hardly be surprising, given their number, the fact that they do not all sit in a single plenary formation and the fact that they do not serve for life. But (our) ignorance about EuC might also be the result of a strategic choice on the part of the ECtHR. The absence of a 'manual' on EuC entails increased flexibility in its use and the ensuing trade-off between judicial discretion and legal certainty, foreseeability and consistency may be what the Court is after when offering its sporadic guidance. ${ }^{40}$ Either way, it is scholarship that strives to bridge this gap by observing the Court's normative attitude and trying to extrapolate the rules of the consensus 'game' from it. Hypothesising and extrapolating, however, comes at a price. When no analytical evaluation of EuC can be premised on an authoritative foundation of the Court's own making, it is inevitable that our understanding of $\mathrm{EuC}$ will remain partial and fragmented, even in so far as its most basic conceptual and functional elements are concerned. ${ }^{41}$

Scholars are not alone, of course, in attempting to cover this lacuna. National governments and their civil service, human rights lawyers representing victims of violations, civil society organisations (especially

37 What we know for certain is that unanimity is not required for the establishment of EuC, although some type of majority will more often than not be deemed necessary. See, for example, Vinter and Others v. the United Kingdom (Appl. no. 66069/09, 130/10 and 3896/ 10), judgment, 9 July 2013, paras 68 and 117, where the Court relied on the practice of the large majority of the contracting states. There are instances in the practice of the Court where the identification of a tendency towards emerging EuC (Schalk and Kopf v. Austria, Appl. no. 30141/04, judgment, 24 June 2010, para. 105) or of emerging consensus per se (Christine Goodwin v. the United Kingdom, para. 84) was not sufficient to reach the consensus threshold.

38 See the Preface in this book by Judge C. L. Rozakis, as well as the chapter by K. Henrard (Chapter 7), who explores the wealth of linguistic choices to which the ECtHR resorts in order to engage with consensus analysis. See also Wildhaber, Hjartarson and Donnelly, 'No consensus on consensus?', 257-8.

39 For the 'copyright' of this play on words, see footnote 3 .

40 See, for example, footnotes 28,29 and 37 on elements of such guidance.

${ }^{41}$ Such ambiguity is evident, for instance, when considering whether elements outside of the practice of the signatories to the ECHR (such as expert opinion or scientific knowledge, and trends informed by the practice of actors outside Europe) can be taken into account for the formulation of consensus. See also footnote 18 . 
when acting as third-party interveners before the $\mathrm{ECtHR}^{42}$ ) and human rights victims themselves are all contributing to the continuous 'writing' of the EuC rulebook. Even with help from all its stakeholders, however, the task of conceptualising, delimiting and deciphering $\mathrm{EuC}$ remains arduous. Trying to gauge where consensus fits in the ECtHR interpretive universe ${ }^{43}$ brings to the fore the methodological challenges of dealing with big data - in this case, the tens of thousands of judgments and decisions that constitute the body of ECtHR jurisprudence. ${ }^{44}$ How certain can one be that one's evaluation of EuC is insulated from selection bias in the choice of the sample?

The challenge of putting together the EuC rulebook in the absence of authoritative guidance by the ECtHR is even greater when one considers that $\mathrm{EuC}$ may be something of a 'moving target', as its definition, function and conditions of usage evolve in the jurisprudence of the Court. ${ }^{45}$ It is, of course, yet another paradox that an interpretive tool intended to capture evolution and to align the content of the ECHR accordingly is itself subject to evolution. But this paradox is, in fact, inevitable given that EuC has been a feature of the ECHR system for several decades ${ }^{46}$ and has been used by scores of judges in dealing with diverse legal questions. The organic way in which $\mathrm{EuC}$ is gradually evolving within the ECHR system, then, is reminiscent of the Rawlsian reflective equilibrium: ${ }^{47}$ the outputs of $\mathrm{EuC}$ depend on the rules of the consensus 'game', but these rules are in turn conditioned and shaped by the outputs. It is natural to assume that the results of consensus analysis ${ }^{48}$ depend on the definition of $\mathrm{EuC}$ and on the rules governing its function. This corresponds to a further assumption, namely that inductive reasoning is at work here. However, there is no real guarantee that all

${ }^{42}$ Which is the topic explored by L. Van den Eynde (Chapter 5) in this book.

${ }^{43}$ Especially if one takes into account that the comparative legal analysis underpinning EuC used to be appreciably weaker in the past. See Dzehtsiarou, European Consensus, pp. 82-4, and Tzevelekos and Dzehtsiarou, 'International custom making', 319-23.

44 In that respect, see our call in the conclusions of this introductory note for quantitative analysis and the references contained in footnote 89.

45 On the evolution of the comparative analysis undertaken by the ECtHR see footnote 43 and especially Dzehtsiarou, European Consensus, pp. 82-101.

46 See footnote 36.

${ }^{47}$ For a different take on how John Rawls' reflective equilibrium can be useful in understanding consensus analysis, see the chapter in this book by J. Theilen (Chapter 17).

48 The establishment, for instance, of a common European standard of protection (because of $\mathrm{EuC}$ ) or the recognition of a wide margin of appreciation (in the absence of EuC) that allows for regulatory pluralism. See footnotes 27 and 28 . 
ECtHR judges or all judgments employing EuC do indeed follow such an inductive route. It may very well be the case that the concealed starting point for some (or many) judges in some (or many) judgments is the concrete standard they find morally (or doctrinally) preferable in a particular instance, which they then justify on the basis of EuC (through a process of 'reverse engineering'). This broadly deductive process is bound to shape not only the 'triggers' of EuC, but also the scope of the Court's discretion in using consensus analysis. The danger of ending up with a circular and somewhat muddled process is evident. When the rules of the EuC 'game' are not known for certain in advance, it is not easy to detect whether and when these rules change during the course of a 'game'. ${ }^{49}$ It is possible that the Court constructs the outputs of EuC by constantly or occasionally (re-)constructing EuC itself as a method. Either way, the underlying theoretical question as to whether the Court's function is constitutive of human rights standards (implying judicial activism) or limited to a mere declaration (i.e., recognition) of human rights standards shaped by EuC remains open. ${ }^{50}$

\subsubsection{Impediments to the Normative Evaluation of EuC}

The aim of Part II of the book is to provide a normative assessment of EuC. Success in that task is inevitably undermined by the difficulties of conceptualising EuC identified thus far. The absence of tangible and robust empirical foundations and the lack of clarity around its meaning and modus operandi make it difficult to answer definitively and unequivocally whether EuC should remain part of ECtHR's toolbox. But there is one more factor that adds to the complexity of this evaluative task, especially if one bears in mind that consensus analysis is, more often than not, drawn from the toolbox to address questions of a particularly sensitive nature. Within the framework of the ECHR system, consensus analysis operates on at least two different levels.

The first level is that of human rights adjudication per se, irrespective, that is, of whether such adjudication takes place before national or

49 See Tzevelekos and Dzehtsiarou, 'International custom making', 335-6, who make a similar point regarding the power of courts to shape the definition of customary international law (which they compare to EuC).

50 Ibid., pp. 316, 317, 330-6. The question encompasses, of course, the way in which the constitutive elements of EuC may have been assessed by the Court through the 'lens' of $\mathrm{EuC}$, which the Court itself constructs. 
supra/inter-national courts. When the answers to sensitive human rights questions are heavily dependent on interpretive choices, the extent to which judges should take account of the reality of socio-political majorities when making said choices is a ubiquitous dilemma in constitutional democracies. In this context, $\mathrm{EuC}$ may be seen as a means for judges to maintain a balance between ex cathedra decision making and decision making informed by the democratic will of majorities (as expressed, for instance, indirectly through parliamentary process or directly through referenda). ${ }^{51}$

The second level on which EuC operates is that of international (human rights) adjudication. The nature of the challenges that come with this particular territory is obvious and well-rehearsed, as is the ubiquitous need for international judges to show appropriate respect for state sovereignty. This is the other potential role of $\mathrm{EuC}$, which may be seen as a way of finding acceptable compromises between the sovereign will of the ECHR signatories (especially when one takes into account the interrelationship between EuC and the margin of appreciation) and the decision-making power of the Court as the last-word, authoritative interpreter of the Convention.

Distinguishing between these two levels, the constitutional and the international, is far from easy, given the dual - international and quasiconstitutional - nature of the Court itself. ${ }^{52}$ As if the picture was not complex enough already, the apparent tensions on these different levels are neither value-neutral nor immune to ideology. It follows that the evaluation of $\mathrm{EuC}$ as a tool of interpretation will depend to an extent on the philosophical preferences of the assessor (e.g., if s/he favours principle-based or majority-stemming human rights standards or what value and meaning s/he ascribes to state sovereignty) and also on the

51 The question of (counter-)majoritarianism in human rights protection and of the role of EuC therein is omnipresent in the relevant literature. For some examples, see footnote 22. The issue is also examined, to various extents, by several chapters in this book: K. Dzehtsiarou (Chapter 2), C. Djeffal (Chapter 4), L. Van den Eynde (Chapter 5), J. Větrovský (Chapter 6), S. Douglas-Scott (Chapter 8), A. Follesdal (Chapter 9), T. Kleinlein (Chapter 10), O. Bassok (Chapter 11), D. Kagiaros (Chapter 13), F. de Londras (Chapter 14), L. Lixinski (Chapter 15) and C. Gearty (Chapter 19).

${ }^{52}$ Regarding the quasi-constitutional nature of the ECHR system, see footnotes 12 and 13. From a very rich relevant literature, see in particular L. Wildhaber, 'A constitutional future for the European Court of Human Rights?' (2002) 23(5-7) Human Rights Law Journal 161-5; A. Stone Sweet, 'On the constitutionalisation of the Convention. The European Court of Human Rights as a constitutional court', Faculty Scholarship Series, Paper 71, 2009, available at http://digitalcommons.law.yale.edu/fss_papers/71. 
level (constitutional or international) the evaluation concerns. ${ }^{53}$ Critiques against $\mathrm{EuC}$ as a method of interpretation may, therefore, come from opposite directions. Some may reject it on the grounds that it overly restricts national regulatory autonomy and state sovereignty, while others may view it as an obstacle to the interpretive recognition of common principles. ${ }^{54}$ Such principles are seen as premised on the moral and philosophical underpinnings of European human rights law, rather than on the volatile will of states and the (majoritarian ${ }^{55}$ ) trends that may prevail in Europe at any given time. Whether or not $\mathrm{EuC}$ is a legitimate and successful tool remains, therefore, very much an open question and one that is closely linked to the wider discourse on the philosophical foundations of human rights ${ }^{56}$ and to the limits of judicial review. ${ }^{57}$ Assessing the legitimacy of EuC and, more generally, evaluating the politics of judicial decision making at the post-national level is, in a sense, tantamount to asking fundamental questions about where the ultimate source of power and authority to decide on morally and politically sensitive human rights issues lies in liberal democratic polities.

There is one final point to make regarding the difficulties in the evaluation of EuC, this time concerning the relationship between $\mathrm{EuC}$ and the legitimacy of the ECtHR. The literature on EuC, both more generally ${ }^{58}$ and in this book in particular, ${ }^{59}$ points to legitimacy both

53 Discussing EuC on the same level of analysis is a conditio sine qua non if we are to avoid arguments that fail to 'speak' in a common tongue.

${ }^{54}$ In this regard, see the seminal work by Letsas, A Theory of Interpretation.

55 See footnotes 22 and 51.

56 For a general overview of the types of issues that the discourse on the philosophy of human rights involves, see R. Cruft, S. Matthew Liao and M. Renzo, 'The Philosophical Foundations of Human Rights: An Overview' in R. Cruft, S. Matthew Liao and M. Renzo (eds), Philosophical Foundations of Human Rights (Oxford: Oxford University Press, 2015).

57 For an excellent recent study on the limits of the constitutional review of primary legislation for its compatibility with human rights, see D. Kyritsis, Where Our Protection Lies: Separation of Powers and Constitutional Review (Oxford: Oxford University Press, 2017), especially chapter 6 . See also G. Tsebelis, 'The time inconsistency of long constitutions', Summer 2017 Bulletin, American Academy of Arts and Sciences, available at www.amacad.org/content/publications/pubContent.aspx?d=32914, explaining that the more difficult it is to amend a constitution (i.e., the more actors endowed with a veto power the process involves), the more discretion is given to courts, that is, the more activist they can be. See also footnote 80 .

58 Dzehtsiarou, European Consensus, pp. 143-76.

59 See the chapters by K. Dzehtsiarou (Chapter 2), A. Follesdal (Chapter 9), C. Gearty (Chapter 19), T. Kleinlein (Chapter 10), O. Bassok (Chapter 11), M. Amos (Chapter 12), E. Bates (Chapter 3), K. Henrard (Chapter 7), S. Douglas-Scott (Chapter 8), L. Lixinski 
as a(n) (internal) goal of the Court and as a(n) (external) criterion for evaluating EuC. Attempting to 'domesticate' a concept as elusive as legitimacy, ${ }^{60}$ however, is inherently challenging. And this is all the more the case if legitimacy is examined in relation to or in juxtaposition with similarly vague and elusive concepts, such as authority. ${ }^{61}$ One cannot help but wonder, then, how EuC can truly be legitimate as a method or increase the Court's external legitimacy when the outputs of consensus analysis may allow for double standards ${ }^{62}$ in human rights protection or may even pave the way towards regression. ${ }^{63}$

(Chapter 15), J. Větrovský (Chapter 6), F. de Londras (Chapter 14), D. Kagiaros (Chapter 13) and J. Kukavica (Chapter 16).

${ }^{60}$ For an overview, see D. Beetham, The Legitimation of Power, 2nd edn (Houndmills: Palgrave Macmillan, 2013), especially chapter 11. On legitimacy in international law, see the seminal work by T. M. Franck, 'Legitimacy in the international system' (1988) 82(4) American Journal of International Law 705-59, especially pp. 725-59. On legitimacy in human rights in international law, see J. Tasioulas, 'Human rights, legitimacy, and international law' (2013) 58(1) The American Journal of Jurisprudence 1-25.

${ }^{61}$ Franck, 'Legitimacy', p. 725. Among other works by A. von Bogdandy, see the papers he co-authored with I. Venzke: 'On the functions of international courts. An appraisal in light of their burgeoning public authority' (2013) 26 Leiden Journal of International Law 49-72; 'In whose name? An investigation of international courts' public authority and its democratic justification' (2012) 23 European Journal of International Law 7-41. The works cited here link authority with legitimacy. On EuC, the authority of the ECtHR and (il)legitimacy, see L. R. Helfer, 'Consensus, coherence and the European Convention on Human Rights' (1993) 26 Cornell International Law Journal 133-65 at 135. See also the contributions by T. Kleinlein (Chapter 10), O. Bassok (Chapter 11) and E. Bates (Chapter 3) in this book.

${ }^{62}$ See in this volume the chapter by D. Kagiaros (Chapter 13) in particular. A typical example of such double standards is the treatment of same-sex unions in the Court's case law. Relying on EuC, the ECtHR has established both a negative (Vallianatos and Others, especially para. 91) and a positive duty (Oliari and others Appl. nos. 18766/11 and 36030/ 11 , judgment, 21 July 2015, especially para. 178) in favour of official recognition of samesex partnership. Mutatis mutandis, because of the absence of EuC, no right to marriage exists for same-sex couples (Schalk and Kopf v. Austria, especially paras 101, 105-6; see also Orlandi and others v. Italy Appl. nos. 26431/12, 26742/12 et al., judgment, 14 December 2017, especially paras 204-5, where the Court reiterated that no right to marriage exists for same-sex couples but found a violation on the basis of the respondent state's failure to provide any form of recognition to a same-sex couple that was married in a third country). This line of jurisprudence has the potential of leading to a separate-butequal regime in Europe, reminiscent of segregation in the United States and elsewhere. V. P. Tzevelekos and P. Kapotas, 'Hell is other people. Three arguments regarding the ECtHR judgment on the exclusion of same-sex couples from civil partnership legislation

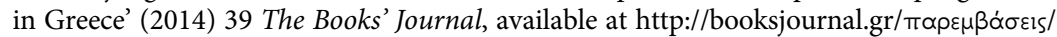

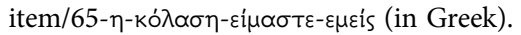

${ }^{63}$ See in this book the chapters by C. Djeffal (Chapter 4), L. Van den Eynde (Chapter 5), D. Kagiaros (Chapter 13), N. N. Shuibhne (Chapter 18) and K. Dzehtsiarou (Chapter 2). 


\subsubsection{Challenges of Comparisons across Legal Systems}

The third part of the book moves beyond the normative borders of the ECHR and explores the 'what' and the 'how' of consensus analysis or analogous interpretive tools in different (national, international and supranational) legal systems, in Europe and beyond. As one would expect, the challenges already discussed remain pertinent for any legal system that consciously favours or avoids consensus-based judicial reasoning in the process of founding human rights standards. But there is one more challenge with which comparative lawyers are painfully familiar and which comes with the territory of considering the role and place of a legal doctrine in different legal systems. It goes without saying that the idiosyncrasies of each legal system and the particularities in the socio-legal environment may have an impact on the way consensus analysis operates. What is of particular significance in this regard is whether the legal systems under scrutiny share a commitment to integrationist goals. ${ }^{64}$ This entails that certain legal systems will be better 'candidates' for a comparison with the ECHR, and such comparisons are more likely to yield fruitful results in so far as consensus analysis is concerned. Regional human rights systems, for instance, may be a closer match to the ECHR system than national (federal) legal systems or the international system of human rights protection, although variations of consensus-based reasoning may find an application in any human rights system.

\subsection{An Ambitious Mapping Exercise: Structure and Contents of the Book}

Although EuC has been part of the ECtHR's interpretative arsenal for quite some time ${ }^{65}$ it did not attract significant academic interest until relatively recently. Admittedly, there is a growing body of academic literature on the question of evolutive/dynamic interpretation of human

64 The significance of integration in this respect is also emphasised by the former Vice President of the ECHR, Judge C. Rozakis, in his Foreword to this book. See also the Preamble to the ECHR and Article 1(a) of the Statute of the Council of Europe, adopted 5 May 1949, entered into force 3 August 1949 ETS 1 . Whether the ECtHR perceives itself as a 'vehicle' for European integration and whether such an integrationist goal is among the Court's priorities is an interesting question that could, perhaps, be the object of another volume.

${ }^{65}$ See footnote 36 . 
rights treaties in general and of the ECHR in particular. ${ }^{66}$ Many papers touch upon EuC tangentially when discussing the margin of appreciation doctrine, ${ }^{67}$ which has a much more prominent place in the literature on the interpretation of the ECHR. ${ }^{68}$ With the exception of a fairly small

66 The literature on evolutive/dynamic interpretation is impressive in its abundance. For some recent examples on the evolutive method in the ECHR system, see K. Dzehtsiarou, 'European consensus and the evolutive interpretation of the European Convention on Human Rights' (2011) 12 German Law Journal 1730-45; K. Dzehtsiarou and C. O'Mahony, 'Evolutive interpretation of rights provisions: A comparison of the European Court of Human Rights and the US Supreme Court' (2013) 44 Columbia Human Rights Law Review 309-65; G. Letsas, 'The ECHR as a Living Instrument: Its Meaning and Legitimacy', in A. Follesdal, B. Peters and G. Ulfstein (eds), Constituting Europe: The European Court of Human Rights in a National, European and Global Context (Cambridge: Cambridge University Press, 2013), pp. 106-41; More generally on the evolutive method, see E. Bjorge, The Evolutionary Interpretation of Treaties (Oxford: Oxford University Press, 2015); C. Djeffal, Static and Evolutive Interpretation. A Functional Reconstruction (Cambridge: Cambridge University Press, 2015). See also footnote 17.

67 See footnote 19.

68 The margin of appreciation has been the object of extensive and thorough analysis in legal scholarship on the ECHR system. Seminal examples include: H. C. Yourow, The Margin of Appreciation Doctrine in the Dynamics of European Human Rights Jurisprudence (The Hague: Kluwer, 1996); Benvenisti, 'Margin of appreciation'; S. Greer, The Margin of Appreciation: Interpretation and Discretion under the European Convention on Human Rights (Strasbourg: Council of Europe, 2000); Y. Arai-Takahashi, The Margin of Appreciation Doctrine and the Principle of Proportionality in the Jurisprudence of the ECHR (Antwerp: Intersentia, 2002); J. A. Brauch, 'The margin of appreciation and the jurisprudence of the European Court of Human Rights: Threat to the rule of law'(2004) 11 Columbia Journal of European Law 113-50; O. Bakircioglu, 'The application of the margin of appreciation doctrine in freedom of expression and public morality cases' (2007) 8 German Law Journal 711-34; Letsas, A Theory of Interpretation; M. Villiger, 'Proportionality and the Margin of Appreciation: National Standard Harmonisation by International Courts', in C. Baudenbacher (ed.), Dispute Resolution (Stuttgart: German Law Publisher, 2009), pp. 207-13; J. Kratochvil, 'The inflation of the margin of appreciation by the European Court of Human Rights' (2011) 29 Netherlands Quarterly of Human Rights 324-57; C. L. Rozakis, 'Through the Looking Glass: An Insider's View of the Margin of Appreciation', in P. Titiun (ed.), La Conscience des Droits: Mélanges en l'honneur de Jean-Paul Costa (Paris: Dalloz, 2011), pp. 527-37; D. Spielmann, 'Allowing the right margin. The European Court of Human Rights and the national margin of appreciation doctrine: Waiver or subsidiarity of European review?' (2011-2012) 14 Cambridge Yearbook of European Legal Studies 381-418; A Legg, The Margin of Appreciation in International Human Rights Law: Deference and Proportionality (Oxford: Oxford University Press, 2012); M. Kopa, 'The algorithm of the margin of appreciation doctrine in light of the Protocol No. 15 amending the European Convention on Human Rights' (2014) 14 International and Comparative Law Review 35-51; D. Spielmann, 'Whither the margin of appreciation' (2014) Current Legal Problems 1-17; D. Tsaraparsanis, 'The margin of appreciation doctrine: A low-level institutional view' (2015) 35 Legal Studies 675-97; E. Benvenisti, 'The margin of appreciation, subsidiarity, and global challenges to democracy', Global Trust Working Paper, 05/2016; Y. Shany, 'All roads lead to 
number of articles $^{69}$ and the notable exception of Dzehtsiarou's recent monograph, ${ }^{70}$ there is a relative scarcity of studies with a particular focus on $\mathrm{EuC}$, given its theoretical importance and its immediate practical impact on the shaping of European human rights standards.

Although this book intends to make a significant contribution to this body of literature, it would be a mistake to assume that any edited volume can single-handedly address, in a comprehensive manner, the complex nexus of questions that arise in connection to EuC. As we argue in the last section of this introduction, there is considerably more research still to be undertaken, especially when one takes into account that several important issues raised by the use of consensus-based reasoning fall well outside the narrow confines of doctrinal legal analysis and straddle the boundaries of different disciplines. The real ambition behind this volume, then, is to ignite and fuel the process of building consensus on EuC, by studying its theoretical underpinnings and function, by identifying its impact on European human rights law and beyond, and by assessing its merits and shortcomings in the context of three broad and interconnected ${ }^{71}$ themes that constitute the backbone of

Strasbourg? Application of the margin of appreciation doctrine by the European Court of Human Rights and the UN Human Rights Committee' (2017) Journal of International Dispute Settlement 1-19, idx011, https://doi-org.liverpool.idm.oclc.org/10.1093/jnlids/ idx011.

69 Examples include: Helfer, 'Consensus, coherence'; T. König, A. Warntjen and S. Burkhart, 'The European Convention: Consensus without Unity?', in S. Hug (ed.), Policy-Making Processes and the European Constitution: A Comparative Study of Member States and Accession Countries (Abingdon: Routledge, 2006), pp. 23-34; P. Martens, 'Perplexity of the National Judge Faced with the Vagaries of European Consensus', in Dialogue between Judges (Strasbourg: Council of Europe, 2008), available at www.echr.coe.int/Documents/Dialogue_2008_ENG.pdf; J. L. Murray, 'Consensus: Concordance, or Hegemony of Majority', in Dialogue between Judges (Strasbourg: Council of Europe, 2008), available at www.echr.coe.int/Documents/Dialogue_2008_ENG.pdf; J. A. Brauch, 'The dangerous search for an elusive consensus: What the Supreme Court should learn from the European Court of Human Rights' (2008-2009) 52 Howard Law Journal 277-318; Dzehtsiarou, European Consensus; D. Regan, 'European consensus: A worthy endeavour for the European Court of Human Rights' (2011) 14 Trinity College Law Review 51-76; E. Myjer, 'Pieter van Dijk and his Favourite Strasbourg Judgment: Some Remarks on Consensus in the Case Law of the European Court of Human Rights', in M. van Roosmalen et al. (eds), Fundamental Rights and Principles: Liber Amicorum Pieter van Dijk (Cambridge: Intersentia, 2013), pp. 49-71; Wildhaber, Hjartarson and Donnelly, 'No consensus on consensus?'; K. Dzehtsiarou and R. Pavel, 'European Consensus and the EU Accession to the ECHR', in V. Kosta et al., The EU Accession, pp. 309-23; Tzevelekos and Dzehtsiarou, 'International custom making'.

70 Dzehtsiarou, European Consensus.

${ }^{71}$ See footnote 8. 
the book. These three broad themes correspond to the three Parts of the book. Parts I and II begin with a short introductory note intended to offer a critical prelude to and set the scene for the chapters that follow, and which showcases the work of (both early career and established) scholars from different disciplinary legal perspectives, including human rights, public international law, comparative constitutional law, EU law, legal theory and philosophy. Part III follows a distinctive route and moves away from EuC 'proper' and the jurisdictional focus on the ECHR. This final Part examines the possible 'spill-over' of EuC as a method of judicial interpretation; as such, it is comprised by an eclectic selection of comparative chapters discussing consensus analysis or similar methods of interpretation in the context of EU law, the Inter-American system and the US Supreme Court (USSC) jurisprudence. Examination of consensus analysis in the legal regimes included in Part III makes sense without the need for different strands to be 'pulled together' by an introduction. The book ends with a concluding chapter by Gearty that brings together the three themes and casts a critical eye on the place and role of consensus analysis in the ECHR system and in human rights law adjudication more generally.

\subsubsection{The Conceptualisation of EuC}

The first Part of the book is devoted to the conceptualisation of EuC. It purports to provide the definitional groundwork for $\mathrm{EuC}$ and explore its modus operandi. Chapters in this Part discuss the history of EuC, ${ }^{72}$ the logic and methodology underpinning its function, and the relationship between EuC and its altera pars, the margin of appreciation doctrine. ${ }^{73}$ They consider where consensus analysis is situated within the bigger picture of international treaty interpretation, ${ }^{74}$ and they pursue lines of enquiry that enhance our understanding of the mechanics, content and role of EuC in the jurisprudence of the ECtHR.

The questions explored in this first Part are as wide-ranging as the methodologies on display, and they reflect the depth and width of the controversies that EuC generates, as Dzehtsiarou points out in his introductory note. Notwithstanding and despite the apparently different

\footnotetext{
72 Especially Chapter 3 by E. Bates.

73 See footnote 19.

74 See footnotes 9-11.
} 
perspectives they adopt, chapters in this part 'converse' with one another and create a rich and nuanced conceptual canvas.

Bates, for instance, explores the historical role of consensus in the development of the Convention system from its early years up to its coming of age at the end of the twentieth century. He argues that, throughout this 'legitimacy-building era', resort to consensus analysis was an essential component of the Strasbourg 'success story', as it reflected the reliance of the Convention system on an underlying 'political consensus' of states on common European standards. Along similar lines, both Henrard and Djeffal cast a critical eye on the what, the how and the why of consensus analysis within the Convention system. Henrard does so in light of the Convention's overarching goal of effective human rights protection. She argues that the Court uses $\mathrm{EuC}$ as a means of justifying the appropriate level of scrutiny of restrictions, taking into account both epistemological and legitimacy concerns. Djeffal, on the other hand, attempts to reveal the internal logic of the consensus doctrine within the Convention system through a four-stage analytical framework that is designed to look at the definition, the function, the ascertainment and the outcome of the EuC doctrine. He is keen to point out that the Court should use $\mathrm{EuC}$ in the context of proportionality assessment and balancing, rather than for the purpose of treaty interpretation.

Van den Eynde turns to examine consensus from the perspective of (one category of) 'end users', looking at the use of the $\mathrm{EuC}$ argument in the amicus curiae briefs submitted to the ECtHR Grand Chamber by non-governmental organisations (NGOs). In doing so, she provides a much-needed empirical backdrop to the wider debate on the meaning and function(s) of EuC. Větrovský is also interested in usage and users, but moves the focus of enquiry in a slightly different direction. Taking his cue from the common supposition in $\mathrm{EuC}$ scholarship that there is no single definition of 'consensus', he argues that scholars, true to a Platonic philosophical tradition, are mistaken in presuming that the absence of 'essential properties' in the Court's definition of EuC renders the concept flawed or unworkable for users (including the Court itself). $\mathrm{Be}$ that as it may, Douglas-Scott highlights that the story of $\mathrm{EuC}$ is one of convergence of different European legal systems and human rights cultures towards 'a shared human rights disposition'. In considering whether this convergence may have been arrived at through different evolutionary routes, Douglas-Scott draws insights from the case law of the Court, while also enlisting the help of master story-teller Jorge Luis Borges. 


\subsubsection{The Normative Evaluation of $\mathrm{EuC}$}

The second Part takes a more evaluative turn, moving on to question the usefulness, appropriateness and desirability of both $\mathrm{EuC}$ per se and its outputs. The emphasis here is primarily on normative analysis that purports to grapple with broader questions of legitimacy. ${ }^{75}$ After all, $\mathrm{EuC}$ is a method of interpretation that permits an international, quasiconstitutional court to recognise and set standards of human rights protection that are absent from the text of the Convention and which might even go beyond the will and intentions of its drafters. ${ }^{76}$ As already argued, a number of moral and political dilemmas underpin the analytical endeavours undertaken in this Part of the book, including the dilemma on the appropriate level of decision making (international or national) ${ }^{77}$ and the dilemma on the final arbiters (courts or parliaments) when it comes to questions pertaining to the protection of rights in democratic societies. ${ }^{78}$ This latter dilemma may be seen as echoing Ronald Dworkin's seminal work on the appropriate basis for judicial decision making (the 'principles v. policy' dichotomy, especially in hard cases).$^{79}$ But it is also reminiscent of well-documented academic debates on whether and to what extent majoritarian justifications may be legitimate or even crucial in answering human rights questions and what role (international) courts can (or should) play in that respect. ${ }^{80}$ The countermajoritarian thesis is prevalent in general human rights scholarship, and

${ }^{75}$ See also footnotes 59,60 and 61.

${ }^{76}$ Cf. Bjorge, The Evolutionary Interpretation, p. 2, associating the evolutive interpretation with the intention of the signatories to a treaty.

77 See also footnote 30 on the obvious links to the doctrine of subsidiarity.

78 This is a question addressed to different extents and from different perspectives in a number of chapters in the book, but see especially the contribution by T. Kleinlein (Chapter 10), who discusses the foundations of the democratic legitimation of the ECtHR in light of the emerging doctrine of procedural rationality.

79 R. Dworkin, Taking Rights Seriously (Cambridge, MA: Harvard University Press, 1978), pp. 82 et seq. See also in this book the chapters by S. Douglas-Scott (Chapter 8) and J. T. Theilen (Chapter 17).

80 Admittedly, these types of questions may be examined from a variety of perspectives. Examples include the representation-reinforcing theory and the so-called new public law movement in the United States, justifying judicial intervention to correct democratic failure. See, for instance, W. N. Eskridge and G. Peller, 'The new public law movement: Moderation as a postmodern cultural form' (1991) 89 Michigan Law Review 707, and J. H. Ely, Democracy and Distrust: A Theory of Judicial Review (Cambridge: Harvard University Press, 1980). See also footnote 56. 
the same is true about the body of work focusing on EuC, including many of the contributions in this book. ${ }^{81}$

Drawing from this rich literature, Follesdal, in his introductory note, pulls together common threads that run across the chapters in this Part of the book. After sketching the Court's practice and identifying several ambiguous aspects of it, he goes on to suggest that, although EuC analysis does not render the ECtHR interpretation of a particular Convention provision more democratic, it may still help uncover hitherto unnoticed discrimination against certain groups. This later point is put forward most forcefully by Kagiaros, who argues that the weight the Court places on $\mathrm{EuC}$ in discrimination cases has been inconsistent. While, in some cases, the Court takes full advantage of the flexibility of the consensus tool to reinforce the minority status of the applicants and to narrow the margin of appreciation, in other cases, the existence or lack of consensus seems to be the sole determining factor to the outcome of the application.

The difficult relationship between EuC and the Court's democratic legitimacy constitutes the focal point for most chapters in this Part. Bassok claims that much of the difficulty that runs deep into the ECtHR's use of the EuC doctrine can be explained when one considers the pivotal role of EuC in the Court's understanding of its own legitimacy. Using an empirical analysis of the ECtHR's judgments, Bassok demonstrates that the ECtHR views judicial legitimacy as predicated on public confidence. By ensuring, then, that its judgments reflect consensus in the contracting states, the Court strengthens its claim to public confidence and legitimacy. Kleinlein offers a different explanation of the link between EuC and the Court's legitimacy, relying on two models of legitimation developed by legal scholars specifically for the democratic legitimation of international and domestic courts: a 'formal model' and a 'control model'. He identifies patterns in the Court's case law in which the Court seems to combine $\mathrm{EuC}$ with a procedural approach to the margin of appreciation, and he argues that such a legitimation strategy opens up spaces for democratic contestation and deliberation.

Amos attempts to test whether such a legitimation strategy based on $\mathrm{EuC}$ has been successful in assuaging British concerns with the Court and the Convention system, and in keeping the UK on side in the postBrighton era. Her analysis reveals that consensus-based reasoning is no match for highly politicised issues, where what really matters is the

81 See footnotes 22 and 51. 
degree of domestic support for the underlying moral message of the judgment. De Londras turns this line of enquiry on its head and considers what happens when EuC clashes with the democratic will of the people as expressed through referenda at the national level. She examines whether a referendum-emergent constitutional provision that goes against consensus at the European level ought to be treated as sufficiently weighty to preserve a wide margin of appreciation for the 'outlier', and she cautions against the possible use of EuC by the Court as a way of avoiding taking a stance on difficult questions.

\subsubsection{Consensus Analysis Outside the ECHR System}

The third Part of the book considers whether interpretive methodologies similar to $\mathrm{EuC}$ are (or should be) part of judicial reasoning in contiguous or comparable legal systems. As already explained, this comparative exercise encompasses different types of legal systems, from a regional mechanism of human rights protection with its own normative and institutional framework (the Inter-American system), ${ }^{82}$ to a system overlapping with the ECHR on issues of rights protection (European Union Law), ${ }^{83}$ and a national legal order that exerts considerable influence in the development of human rights doctrine worldwide (the United States, and in particular, US constitutional law). The role of the respective courts - the Inter-American Court of Human Rights (I-ACtHR), the Court of Justice of the European Union (CJEU) and the USSC - that drive interpretive progress in these systems is crucial. Contributions in this part of the book examine whether analogies can usefully be drawn between $\mathrm{EuC}$ and comparable doctrines in other jurisdictions and whether EuC itself has transferable qualities that may render its transplantation into different systems possible and desirable.

Starting with the Inter-American system, Lixinski argues that the I-ACtHR uses consensus analysis tentatively and as a subsidiary interpretive tool, as the Court's true allegiance lies with the pro homine principle that favours interpretations of human rights. When the I-ACtHR seeks consensus, Lixinski claims, it does so more often in the international legal order than in the domestic law and practice of the states parties to the Inter-American system, which seems to suggest that the Court is using consensus analysis as a means of systemic integration.

${ }^{82}$ See the chapter by L. Lixinski (Chapter 15).

${ }^{83}$ See the chapters by J. T. Theilen (Chapter 17) and N. N. Shuibhne (Chapter 18). 
The USSC, on the other hand, is closer to the ECtHR in how it incorporates consensus analysis in its reasoning. In fact, according to Kukavica, not only does the USSC resort to 'national consensus' in its Eighth Amendment jurisprudence, but it also conceptualises consensus in a more consistent manner compared to the ECtHR. Through this direct comparison, Kukavica is able to make suggestions on possible courses of action with a view to improving the clarity and consistency of EuC in the ECHR system.

Back on European normative soil, Shuibhne explores how consensusbased reasoning has (not) shaped the CJEU jurisprudence on EU citizenship. Despite an apparent but partial nod to an EU version of consensus analysis in an early ruling, the CJEU has steered clear from consensus analysis when determining the 'practical effect' of freedom of movement and citizenship rights. Shuibhne leads us first down a counterfactual path, considering whether the absence of a more consensus-based approach in the formative years of EU citizenship law was a missed opportunity. Her analysis then moves in a more prospective direction, attempting to gauge the implications of a possible emerging national consensus that could challenge current EU citizenship law.

This line of enquiry is picked up by Theilen, albeit within a slightly different context. They set out to examine how the ECtHR and the CJEU use vertically comparative reasoning (rather than consensus analysis per $s e$ ), that is, comparative reference to the national laws of the states parties to the respective systems. Theilen acknowledges that the two European courts belong to different adjudicatory cultures and argues that this may explain why the CJEU opts for general references to common constitutional principles, while the ECtHR makes concrete references to national applicable laws. What Theilen proposes is that the correct balance on the generality/specificity (of comparisons) spectrum can be found by making use of a theoretical construct akin to a Rawlsian reflective equilibrium.

\subsection{Epilogue: A Note on Limits and Limitations}

The key question with which this introductory note attempts to grapple is whether and how it is possible to accurately conceptualise the EuC 'game' and understand its modus operandi, when the 'game master' has not offered a convincing and comprehensive rulebook. The answer to this key question reflects the ambition of this book, but also its limitations. What we aim to do is contribute to the conceptualisation of EuC, not only because of the importance of this interpretive tool per se, but also because understanding the rules of consensus-based reasoning is a precondition 
for assessing its value and desirability in the ECHR system, as well as its transferability across comparable legal systems. It is important to bear in mind that disagreements on the nature and modus operandi of EuC will inevitably boil down to disagreements on fundamental questions regarding the powers and role of the ECtHR in the European polity/ies, as the final arbiter of morally and politically delicate choices.

The extent to which this book can actually contribute to the building of a consensus on consensus, however, will hinge on how successfully it can overcome the obstacles identified in Section 1.3 of this chapter. As we already explained, a lot depends on whether EuC, as a tool, is static or dynamic (itself subject to evolution) and conceptually fixed as a singular 'entity' or a conceptual 'matrix' from which the Court derives or constructs up-to-date human rights standards. ${ }^{84}$ There are two final words of caution that we feel we owe our readers.

The first concerns the sheer range of questions one may ask on or around EuC. We are aware of the fact that the confines of a project like ours inevitably entail that important questions will be left underexplored or untouched. Whether national referenda, for instance, are an acceptable source for the establishment of human rights and whether EuC should be informed by referenda could be the object of a separate book. The same is true with regard to the possibility of a 'regressive consensus' and the associated question of lowering human rights standards, which is especially pertinent at times of a revival of nationalisms in Europe and elsewhere, of an enfeeblement of the état de droit within illiberal democracies and of growing scepticism vis-à-vis the ECHR system. ${ }^{85} \mathrm{~A}$ different route would be to examine EuC purely from the perspective of public international law. Regardless of the interrelationship between $\mathrm{EuC}$ and other methods contained in the VCLT, it would be useful to research more thoroughly the usefulness of EuC in the interpretation of jus cogens rules or whether EuC is akin to customary international law. ${ }^{86}$ And, of course, the use of consensus-based reasoning outside the ECHR system is

84 See footnotes 49 and 50.

85 Regarding the latter aspect, see especially in this book the chapter by M. Amos (Chapter 12).

86 On that question, see Tzevelekos and Dzehtsiarou, 'International custom making'; V. P. Tzevelekos, 'The Making of International Human Rights Law', in C. M. Brölmann and Y. Radi (eds), Research Handbook on the Theory and Practice of International LawMaking (Cheltenham: Edward Elgar, 2016), pp. 329-53 at pp. 345-7; and especially and more authoritatively, I. Ziemele, 'Customary international law in the case law of the European Court of Human Rights. The method' (2013) 12 The Law and Practice of International Courts and Tribunals 243-52. 
only partially covered in the book. ${ }^{87}$ Whether and how far consensus analysis is or should be used in federal national systems or in the UN system of human rights protection remains, to a large extent, underexplored. ${ }^{88}$ Interesting and important as such questions may be, there is only so much one edited collection can do.

The second word of caution is methodological and speaks to the interdisciplinary nature of the enquiry. Although we concede that lawyers should be at the forefront of answering questions pertaining to the protection of rights, this does not mean that the methods used in such an evaluative endeavour should remain confined to one discipline. As such, we are strong advocates of the need to enlist help from different disciplinary backgrounds and to establish collaborations that straddle traditional disciplinary boundaries, if we are to get a clear sense of the full picture. We strongly believe, therefore, that $\mathrm{EuC}$ should (also) be explored by social scientists using advanced quantitative methods of analysis as a means to provide a solid empirical foundation for its conceptualisation. ${ }^{89}$ We concede, of course, that there is still a lot of ground to cover in this direction. But, for lawyers and social scientists alike, this is reason for optimism more than anything else. After all, as long as the ECtHR continues to refuse to draw an authoritative 'roadmap' on EuC, this task will continue to rest primarily with academia.

87 See the chapter by J. Kukavica (Chapter 16).

${ }^{88}$ But see on the UN system, for example, Shany, 'All roads lead to Strasbourg?'.

${ }^{89}$ Quantitative text analysis has been employed extensively and for various purposes with regard to the USSC. For examples, see P. C. Corley, P. M. Collins Jr and B. Calvin, 'Lower court influence on U.S. Supreme Court opinion content' (2011) 73 The Journal of Politics 31-44; M. Evans, W. V. Mclntosh, L. Lin and C. L. Cates, 'Recounting the courts? Applying automated content analysis to enhance empirical legal research' (2007) 4 Journal of Empirical Legal Studies 1007-39. Quantitative analysis of the ECHR regime, on the other hand, is limited, with the notable exception of E. Voeten. The data he has collected is available at: http://faculty.georgetown.edu/ev42/ICdata_files/Page364.htm. See E. Voeten, 'Domestic implementation of European Court of Human Rights judgments: Legal infrastructure and government effectiveness matter: A reply to Dia Anagnostou and Alina Mungiu-Pippidi' (2014) 25 European Journal of International Law 229-38. See also the very recent work by N. Aletras, D. Tsarapatsanis, D. Preoțiuc-Pietro and V. Lampos, 'Predicting judicial decisions of the European Court of Human Rights: A natural language processing perspective' (2016) PeerJ Computer Science, DOI 10.7717/ peerj-cs.93. 